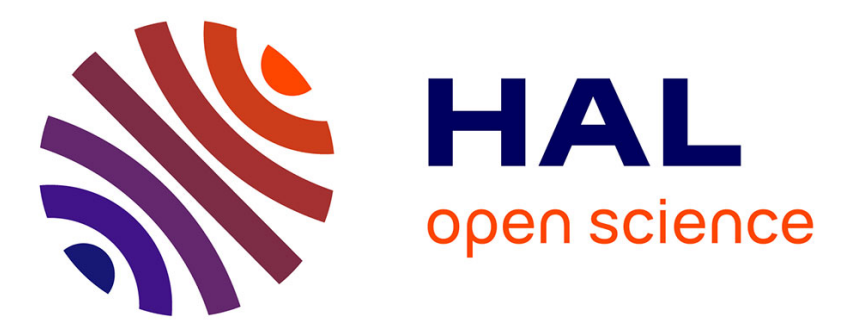

\title{
Corrigendum to "Floating hollow carbon spheres for improved solar evaporation" [Carbon 146 (2019) 232-247]
}

A. Celzard, A. Pasc, S. Schaefer, K. Mandel, T. Ballweg, S. Li, G. Medjahdi, V. Nicolas, V. Fierro

\section{To cite this version:}

A. Celzard, A. Pasc, S. Schaefer, K. Mandel, T. Ballweg, et al.. Corrigendum to "Floating hollow carbon spheres for improved solar evaporation" [Carbon 146 (2019) 232-247]. Carbon, 2019, 150, pp.549. 10.1016/j.carbon.2019.04.103 . hal-03042954

\section{HAL Id: hal-03042954 \\ https://hal.univ-lorraine.fr/hal-03042954}

Submitted on 19 Dec 2020

HAL is a multi-disciplinary open access archive for the deposit and dissemination of scientific research documents, whether they are published or not. The documents may come from teaching and research institutions in France or abroad, or from public or private research centers.
L'archive ouverte pluridisciplinaire HAL, est destinée au dépôt et à la diffusion de documents scientifiques de niveau recherche, publiés ou non, émanant des établissements d'enseignement et de recherche français ou étrangers, des laboratoires publics ou privés.

\section{(ㅇ)(1) $\$$}

Distributed under a Creative Commons Attribution - NonCommercial - NoDerivatives 44.0 


\title{
Corrigendum
}

\section{Corrigendum to "Floating hollow carbon spheres for improved solar evaporation" [Carbon 146 (2019) 232-247]}

\author{
A. Celzard ${ }^{\text {a, }}$, A. Pasc ${ }^{\text {b }}$, S. Schaefer ${ }^{\text {a }}$, K. Mandel ${ }^{c, d}$, T. Ballweg ${ }^{c}$, S. Li ${ }^{\text {b }}$, \\ G. Medjahdi ${ }^{\mathrm{e}}$, V. Nicolas ${ }^{\mathrm{a}}$, V. Fierro ${ }^{\mathrm{a}}$ \\ ${ }^{a}$ Université de Lorraine, CNRS, IJL, F-88000, Epinal, France \\ ${ }^{\mathrm{b}}$ Université de Lorraine, CNRS, L2CM, F-54000, Nancy, France \\ ${ }^{c}$ Fraunhofer Institute for Silicate Research ISC, D-97082, Würzburg, Germany \\ ${ }^{\mathrm{d}}$ Chair of Chemical Technology of Materials Synthesis, Department Chemistry and \\ Pharmacy, Julius-Maximilians-Universität Würzburg Röntgenring 11, 97070, \\ Würzburg, Germany \\ ${ }^{\mathrm{e}}$ Université de Lorraine, CNRS, IJL, F-54000, Nancy, France
}

The authors regret that the printed version of the above article contained some errors in the value of the lower bound of thermal conductivity considered and discussed in section 3.5. The correct and final version follows. The authors would like to apologise for any inconvenience caused.

The penultimate paragraph of section 3.5 should read: "This range, which is already unrealistically broad, was widened further to $0.02-10 \mathrm{~W} \mathrm{~m}^{-1} \mathrm{~K}^{-1}$, and those extreme values were tested. The results are shown in Fig. 14. It can be seen that the impact of the thermal conductivity is quite low since a change of less than $10 \%$ was obtained. This finding definitely suggests that the effect observed by Zhou et al. [4] was not attributable to some differences of thermal conductivity but to another physical properties of their HCSs, since the authors could only multiply the conductivity by a factor 1.23 (against 500 in the simulation) by changing the composition of their materials."

The new Fig. 14 is thus the following (only the legends written inside the plots are modified, not the plots themselves). 
(a)

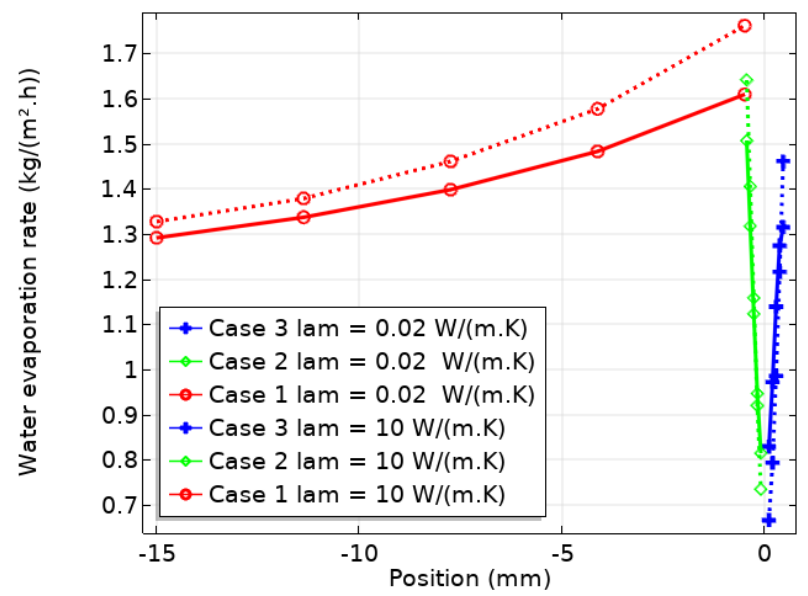

(b)

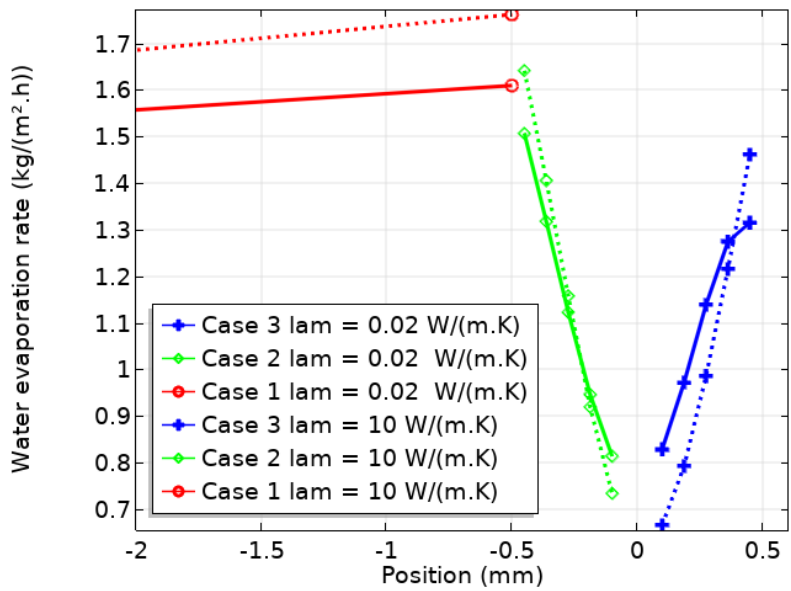

Fig. 14. Calculated change of evaporation rate as a function of the position of the HCS, for two extreme values of its thermal conductivity, $\lambda$ ("lam" on the plots). (b) is a zoom of (a) in the range of positions where the water evaporation changes the most. (A colour version of this figure can be viewed online.)

DOI of original article: $10.1016 /$ j.carbon.2019.01.101 DOI of corrected article: <insert DOI of rerun article> Alain Celzard, Université de Lorraine, CNRS, IJL, F-88000, Epinal, France alain.celzard@univ-lorraine.fr 